\title{
Angiotensin Receptor Type I Blockade Inhibits Apoptosis in Meconium-Instilled Rabbit Lungs
}

\author{
Alexander Zagariya ${ }^{1}$, Shan Navale ${ }^{2}$, Bruce Uhal ${ }^{3}$, Olga Zagariya ${ }^{4}$, Dharmapuri Vidyasagar ${ }^{4}$ \\ ${ }^{1}$ Cancer Center, University of Illinois at Chicago, Chicago, USA; ${ }^{2}$ Division of Cardiology, Northwestern University at Chicago, \\ Chicago, USA; ${ }^{3}$ Department of Physiology, Michigan State University, East Lansing, USA; ${ }^{4}$ Division of Neonatology, University of \\ Illinois at Chicago, Chicago, USA. \\ E-mail: zagariya@uic.edu
}

Received May $14^{\text {th }}, 2011$; revised August $31^{\text {st }}, 2011$; accepted September $15^{\text {th }}, 2011$.

\begin{abstract}
Background and objectives: In prior studies we demonstrated that meconium-induced lung cell death by apoptosis was associated with activation of the local pulmonary renin-angiotensin system $\left(R A S_{L}\right)$. Alveolar epithelial apoptosis requires the authocrine synthesis and proteolytic processing of angiotensinogen (AGT) to Angiotensin II (ANG II). Inhibitors of angiotensin converting enzyme (ACE) block meconium-induced apoptosis. ANG II plays an essential role in vascular homeostasis and lung injury. The objectives of this study were to evaluate expression of AGT, ANG II and Caspase 3 in meconium and saline treated newborn lungs and to study mechanisms of its inhibition by a selective antagonist of the AT1 receptor. Methods: Two week old rabbits were studied. Three treatment groups were studied (six rabbit pups in each group): Group 1: rabbits instilled with saline; Group 2: rabbits instilled with 10\% meconium; Group 3: Losartan pretreated followed by meconium-instillation. Three groups of A549 human lung epithelial cells were studies as well. Group 4: AGT pretreated and then meconium-exposed cells; Group 5: ANG II pretreated and then meconium exposed cells and Group 6: Caspase 3 inhibitor ZVAD-fmk pretreated and then meconium exposed cells. $A G T, A N G$ II and Caspase 3 were evaluated and compared with and without inhibitors in meconium and control groups. Results: In Situ End Labeling (ISEL) and Caspase 3 assays showed that purified ANG II induced dose dependent apoptosis in rabbit lung lavage cells and the human A549 lung epithelial cell line. Apoptosis also was induced by purified AGT. The increase in apoptotic cells was accompanied by increases in ANG II and Caspase 3 activities. In both airway epithelium and alveolar wall cells, measures of apoptosis were attenuated by Losartan or by the Caspase 3 inhibitor ZVAD-fmk. Conclusions: These data demonstrate the presence of a functional ANG II and Caspase 3 dependent apoptotic pathways in newborn meconium-instilled lungs. They also imply that meconium-induced apoptosis is modulated by the pulmonary $R A S_{L}$ system in which ANG II plays a critical role. Both losartan and the Caspase 3 inhibitor ZVAD-fmk pretreatment significantly decreased meconium-induced Caspase-3 activation and lung cell apoptosis.
\end{abstract}

Keywords: Meconium, Lungs, Apoptosis, Angiotensinogen, Angiotensin II, Captopril

\section{Introduction}

Newborn lung epithelial cells play an important role in lung recovery after injury and during normal development $[1,2]$. Previously we demonstrated meconium-induced lung cell apoptosis in 2-week-old rabbits in vivo [3]; apoptosis refers to accumulation of actively dying cells, cell shrinkage, membrane bending, chromatin condensation and DNA fragmentation [4]. ANG II-induced lung cell apoptosis can also be significantly inhibited by the angiotensin converting enzyme (ACE) inhibitor Cap-

*Funding: This study was supported by a grant from the Thrasher Foundation. topril [5]. Interestingly, TNF $\alpha$ [5,6] and FAS [7] induced apoptosis of lung epithelial cells require ANG II generation and activation of ANG receptors [5-8]. The majority of biologic effects of ANG II, including vasoconstriction, growth, proliferation, hypertension, and fluid and electrolyte regulation is mediated via its AT1 and AT2 receptors $[9,10]$. The role of these receptors in lung injury by meconium is still unclear. For these reasons, we hypothesized that meconium-induced lung cells apoptosis might be induced by ANG II through pathways involving conversion of AGT to ANG II by angiotensin converting enzyme (ACE) and subsequent binding of ANG II to the AT1 receptor. 
Caspase 3 has been shown to play an important role as a downstream member of the protease cascade, in which various cell death pathways converge into the same effector pathway [11]. In inducing apoptosis, Caspase 3 is proteolytically cleaved into $\mathrm{p} 17$ and $\mathrm{p} 12$ subunits, which then heterodimerize to form the active enzyme [12]. Caspase 3 is activated in Fas-, TNF $\alpha$-, AGT- and meconium-induced apoptosis.

Based on the results mentioned above, it was hypothesized that ANG II and Caspase 3 are both involved in meconium-induced lung cell apoptosis and that their specific inhibition by the ANG II receptor AT1-selective antagonist, Losartan, or by the Caspase 3 inhibitor ZVADfmk would protect against meconium-induced lung cell death, both in vitro and in vivo.

\section{Methods}

\subsection{Reagents}

Caspase 3 inhibitor ZVAD-fmk were from Biomol Co. Losartan was obtained from Merck Co. (West Point, PA). ( $N$-benzylcarboxy-Val-Ala-Asp-fluoromethylketone) was obtained from Clonteck Co. (Palo Alto, CA). DEVD-fmk (Asp-Glu-Val-Asp-fluoromethylketone) was obtained from Pharmingen Co. (San Diego, CA). Angiotensinogen, ANG II and all other materials were of reagent grade and were obtained from Sigma Chemical Co. (St. Louis, MO).

\subsection{Study Design}

Two-week-old New Zealand white rabbit pups (Kuiper Rabbit Ranch Co., Gary, IN, USA) were used in the study. The animals were handled according to the National Institute of Health guidelines. Pups were housed before each experiment with the mother in stainless steel rabbit cages. The mothers were given regular Purina rabbit chow obtained from Scientific Animal Feed Co. (Arlington Heights, IL). The Animal Care and Use Committee of University of Illinois at Chicago, Chicago, approved the experimental protocol.

Three groups of animals were studied (six rabbit pups in each group): Group 1: rabbits instilled with saline; Group 2: rabbits instilled with 10\% meconium; Group 3: Losartan pretreated and then meconium-instilled rabbits.

Also, three groups of A549 human lung epithelial cells were studies as well. Group 4: AGT pretreated and then meconium-exposed cells; Group 5: ANG II pretreated and then meconium exposed cells and Group 6: Caspase 3 inhibitor ZVAD-fmk pretreated and then meconium exposed cells.

Meconium solution was prepared according to previously published procedures [3]. In brief, first pass human meconium samples were obtained from full-term, healthy human neonates and pooled. Before each experiment $1 \mathrm{~g}$ of fresh meconium was homogenized on ice in a blender with $9 \mathrm{ml}$ of $0.9 \% \mathrm{NaCl}$ to a $10 \%$ (weight/volume) final concentration and centrifuged at 5000 RPM for $20 \mathrm{~min}$ $\left(4^{\circ} \mathrm{C}\right)$. The supernatant was filtered using a glass filter followed by sterilization with a $0.2 \mu \mathrm{m}$ filter obtained from Millipore Co. (Bedford, MA). The debris-free supernatant of meconium solution was used in the study.

To examine the effect of local inhibition of the reninangiotensin system (RAS), $50 \mathrm{mg} / \mathrm{L}$ of losartan was instilled in the lungs. All instillations were done as described above for different groups. Prior to lavage, rabbits were anesthetized by intraperitoneal injection of 10 $\mathrm{mg} / \mathrm{kg}$ Ketamine and $1 \mathrm{mg} / \mathrm{kg}$ Xylazine. A small midline incision was made on the ventral aspect of the neck to expose the trachea, and $1.2 \mathrm{ml} / \mathrm{kg}$ of the $10 \%$ sterile meconium supernatant or an equivalent volume of $0.9 \%$ $\mathrm{NaCl}$, was instilled with a $1 \mathrm{ml}$ syringe and a needle followed by a $5 \mathrm{ml}$ bolus of air to disperse the meconium into the lungs. The skin incision was closed with $4-0$ nylon suture, and the pups allowed breathing room air spontaneously. Pups were euthanized using Nembutal $(100 \mathrm{mg} / \mathrm{kg}$, i.p.) at $0,2,4,8$ and $24 \mathrm{hr}$ after meconium or saline injection. Immediately thereafter the chest was opened by a midline incision, lungs were isolated, and lung lavage was performed. The lavage fluid was used to study alveolar cell death.

\subsection{Application of Caspase 3 Inhibitor (ZVAD-fmk) or Losartan}

The A549 human lung airway epithelial cell line was cultured using methods previously described [13] and used for studies no less then $48 \mathrm{hr}$ after passage. All cells were seeded in 24-well or 6-well chambers, and experiments were conducted at $80 \%-90 \%$ densities in serum free Han's F-12 medium. The peptide inhibitor of Caspase 3/systeine protease protein-32/Yama, Asp-Glu-ValAsp-fluoromethylketone (ZVAD-fmk) was obtained from Clontech Co. (Palo Alto, CA), dissolved in dimethyl sulfoxide, and applied to the cells under serum-free conditions for $20 \mathrm{hr}$ at $37^{\circ} \mathrm{C}$ in $5 \% \mathrm{CO}_{2}$ incubator. Caspase 3 activity was assessed in "viable" cells in suspension culture, which were assayed fluorimetrically over the first $\mathrm{hr}$ after addition of the Caspase 3 substrate Ac-DEVDAMC (Upstate Biotechnology, Saranac Lake, NY) at 200 $\mu \mathrm{M}$ final concentration. Levels of Caspase 3 were monitored at an excitation wavelength of $380 \mathrm{~nm}$ and an emission of $460 \mathrm{~nm}$ using a fluorescence place reader. Caspase 3 activity was expressed as fluorescence units per milligram of protein per hour. The protein concentrations were determined using the protein assay kit from BioRad Co. (Hercules, CA).

Studies of ANG II induced Caspase 3 expression was carried according to protocol described by us earlier [7, 
8]. The AT1-selective antagonist, Losartan, was used for instillation into rabbit lungs at a concentration of 50 $\mathrm{mg} / \mathrm{L}$ and for an A549 cell pretreatment in concentrations of 5,10 and $15 \mu \mathrm{M}$.

\subsection{Measurement of ANG II-Induced Apoptosis}

As a marker of apoptosis Caspase 3 activity was measured in A549 lung epithelial cells. For this purpose cells were harvested from culture by plastic scraper, washed with ice-cold PBS and resuspended in normal saline. The cell suspension was lyzed by three cycles of freezing and thawing. The crude cytosol was obtained as the supernatant from centrifugation at $12,000 \mathrm{~g}$ for $20 \mathrm{~min}$ at $4^{\circ} \mathrm{C}$.

To measure of Caspase 3 activity in these cells, the extract was homogenized in normal saline and then crude homogenate was obtained after centrifugation at 12,000 $\mathrm{g}$ for $20 \mathrm{~min}$ at $4^{\circ} \mathrm{C}$. The enzyme reaction mixture contained $0.08 \mu \mathrm{g}$ of rh-Caspase 3 (or $200 \mu \mathrm{g}$ of cytosolic protein) and $400 \mu \mathrm{M}$ Ac-DEVD-pNA in $150 \mu \mathrm{l}$ of buffer B (100 mM HEPES pH 7.4, 20\% glycerol and protease inhibitors). The enzyme reaction was initiated by adding the substrate to a 96-well plate containing the enzyme solution incubated at $30^{\circ} \mathrm{C}$. The Caspase 3 activity was calculated from the initial velocity by measuring absorbance at $405 \mathrm{~nm}$ every $10 \mathrm{~min}$. The reaction mixture without enzyme or substrate was used as a control. Protein content was analyzed using the Bio-Rad assay. Angiotensin II was administered to cells in concentration from 0.4 to $40 \mu \mathrm{M}$.

\subsection{Histological Analysis}

After i.p. Nembutal the lungs were removed, ligated at the hilus and excised. Then lung were cannulated at the bronchus and instilled for $2 \mathrm{hr}$ with $4 \%$ formaldehyde in $\mathrm{PBS}$ at $20-\mathrm{cm} \mathrm{H}_{2} \mathrm{O}$ constant pressure. The fixed tissue was washed in PBS three times for 15 min and embedded in paraffin. All lung sections were cut into $6 \mu \mathrm{m}$ thickness and mounted on glass slides as previously described [3]. Basic staining with hematoxylin-eosin ( $\mathrm{H} \& \mathrm{E})$ of freshly resected lungs was performed and analyzed under magnification of $100 \times$ by light microscopy.

\subsection{Microscopy and Image Analysis}

Lung sections or cell cultures were photographed under transmitted, fluorescence or polarized light on an Olympus BH2 epifluorescent microscope fitted with automatic photographic equipment. Color photographic slides made with tungsten film were converted to digital images by scanning, and the images were analyzed with commercially available image analysis software. Cell viability was detected as described earlier [14]. $1 \times 10^{5}$ cells were grown in 96-well plates for $24 \mathrm{hr}$. After incubation with meconium, ANG II, AGT or Caspase 3 for $18 \mathrm{hr}$, cells were treated with Acrydine Orange and Ethidium Bromide (at about $0.5 \mathrm{mg} / \mathrm{ml}$ each) at $37^{\circ} \mathrm{C}$. Then cell media was removed, cells were lysed in 2-isopropanol containing $0.04 \mathrm{~mol} / \mathrm{L} \mathrm{HCl}$, and green (live cells) and orange (dead cells) were quantitated. We evaluated stained orange cells as a percent of total cells in microscopic field. Five fields were quantified in each group. Means of cell numbers from control and experimental groups were compared.

\subsection{AGT mRNA Expression by RT-PCR}

RT-PCR assay of AGT was performed as described earlier [8,9]. Briefly, total RNA was isolated with the RN easy Mini protocol (Qiagen, Santa Clarita, CA). To synthesize cDNA, $3 \mu \mathrm{g}$ of purified RNA were reverse transcribed with $2 \mathrm{mM}$ oligo (dT), $50 \mathrm{mM}$ Tris- $\mathrm{HCl}$ (pH 8.3), $75 \mathrm{mM} \mathrm{KCl}_{2}, 0.1 \mathrm{mM}$ dithiothreitol, $0.2 \mathrm{mM}$ each deoxynucleotide triphosphate, $1 \mathrm{U} / \mathrm{ml}$ of RNase inhibitor (RNasin), and $2 \mathrm{U}$ of avian myoblastosis virus reverse transcriptase (Promega, Madison, WI) in a total volume of $30 \mu \mathrm{l}$. The reaction was performed for $1 \mathrm{hr}$ at $42^{\circ} \mathrm{C}$ followed by 20 cycles of PCR amplification.

PCR amplification was performed as follows: cDNA (10 $\mu \mathrm{l}$, equivalent to $1 \mu \mathrm{g}$ ) was adder to $50 \mu \mathrm{l}$ of PCR buffer: $5 \mathrm{mM} \mathrm{MgCl} 2,5 \mu \mathrm{g} / \mathrm{ml}$ each of 5' and 3' primers (see below), $2 \mu \mathrm{l}$ of $10 \mathrm{mM}$ deoxynucleotide triphosphates, and $1 \mathrm{U}$ of Taq polymerase (Promega) with a Perkin-Elmer PCR amplifier. Denaturation was done at $95^{\circ} \mathrm{C}$ for $30 \mathrm{~min}$. Annealing of primers for $30 \mathrm{sec}$. Elongation of the chain at $72^{\circ} \mathrm{C}$ for $1 \mathrm{~min}$ with $1 \mathrm{u}$ Taq DNA polymerase. Samples were stored at $4^{\circ} \mathrm{C}$. Negative controls were DNA free. Identity of the expressed genes was determined by the expected size of the PCR product on $1.6 \%$ agarose gels.

AGT primers were: coding, 5'-GCTTCAACACCTACGTCCA-3', and uncoding, 5'-AGCTGTTGGGTAGACTCTGT-3'. These primers yielded a final PCR product of 447 bp [15]. For $\beta$-actin, single step RT-PCR was used with the primers coding: 5'-AGGCCAACCGCGAGAAGATGACC-3', and uncoding: 5'-GAAGTCCAGGGCGACGTAGC-3', which produced a PCR product of $332 \mathrm{bp}$ [16].

\subsection{Data Analysis}

All measurements were compared using ANOVA for multiple groups of rabbits and cells. Results of each parameter within a group were expressed as mean \pm standard deviations. In morphological experiments 500 cells per sample were counted. Paired evaluations were made for experimental and control conditions within each experiment, and significance determined. Statistical significance was taken as $\mathrm{p}<0.05$. 


\section{Results}

Apoptosis was quantitated by evaluation of nuclear fragmentation determined by ISEL, Caspase 3 activation and morphological studies of lung histology under light and fluorescent microscope.

\subsection{ISEL Labeling for DNA Fragmentation}

Figure 1 shows in situ end labeling (ISEL) of DNA fragmentation. This labeling shows that meconium and ANG II cause a significant increase of lung cell apoptotic cells (Figure 1, Panel E). Pretreatment of rabbits by AT1 receptors inhibitor, Losartan (Figure 1(c)) or Caspase 3 inhibitor ZVAD-fmk (Figure 1(d)) dramatically reduced the level of meconium-induced lung cell apoptosis. Apoptotic cells are shrunken with condensed nuclei and chromatin. ISEL labeled cells are dark blue compared to healthy cells, which are clear or pink.

\subsection{Meconium, AGT and ANG II Increase Caspase 3 Expression}

The caspases play key roles in apoptotic processes [17]; for this reason the effects of meconium (Figure 2(a)), AGT (Figure 2(b)) and ANG II (Figure 2(c)) on Caspase 3 activity were investigated. Figure 2 shows that $10 \%$ meconium, AGT and ANG II all activate Caspase 3 activity in A549 cells by at least $120 \%-130 \%$ compared with unstimulated cells. Specificity of Caspase 3 activation was suggested by an increase of total cell viability in presence of the pan-caspase inhibitor ZVAD-fmk. This finding documented direct involvement of caspase activity in ANG II-induced and meconium-induced apoptosis and DNA fragmentation.

\subsection{ANG II-Induced Apoptosis}

ANG II-induces apoptosis in dose-dependent manner in A549 human lung cells. For quantitative analysis of apoptotic changes, equal amount of cells $(10,000$ cells per well, 24-well plates) were incubated in media containing either buffer (control) or $10^{-12}$ to $10^{-6} \mathrm{M}$ ANG II for $16 \mathrm{hr}$ at $37^{\circ} \mathrm{C}$. Purified ANG II induce apoptosis in both rabbit pup lungs and human A549 cell line (Figure 1(e)). To confirm the detection of apoptosis, equal numbers of cells were incubated in 100-mm Petri dish with media containing either buffer (control) or $10^{-6} \mathrm{M}$ ANG II for $16 \mathrm{hr}$. Then DNA was isolated and electrophoresed. Apoptotic DNA showed a classic ladder pattern (not shown), also confirming occurrence of apoptosis.

In rabbits, maximal ANG II-induced apoptosis was observed after DNA fragmentation studies. Interestingly, that prolonged incubation with ANG II for 12 or $24 \mathrm{hr}$ did not lead to a further increase of DNA fragmentation.

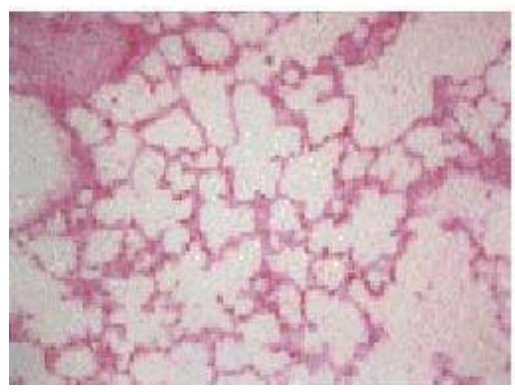

(a)

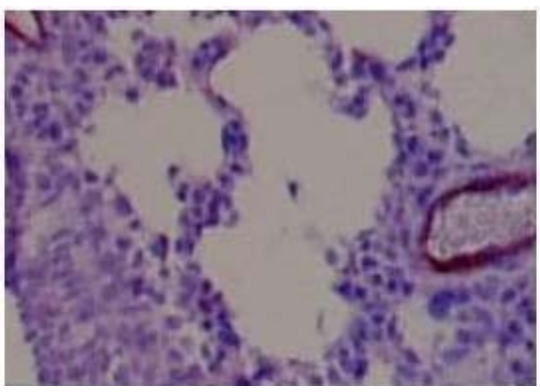

(b)

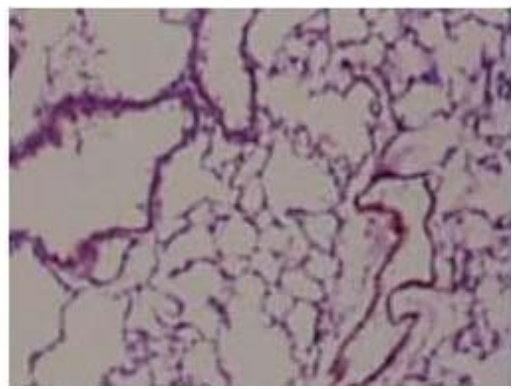

(c)

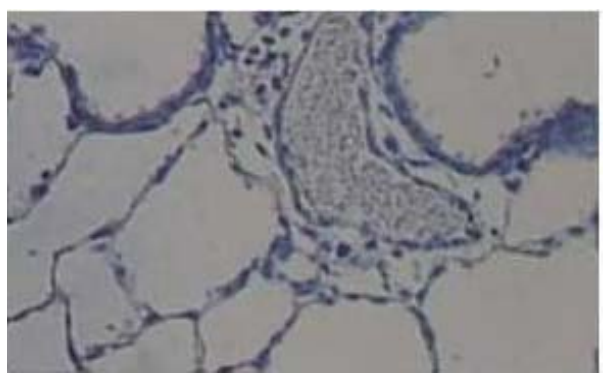

(d)

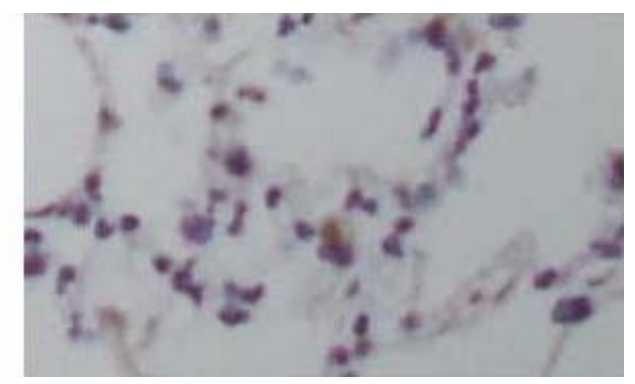

(e)

Figure 1. Evaluation of apoptosis by ISEL labeling for DNA fragmentation. (a) Control group, instilled with normal saline; (b) instilled with $10 \%$ meconium. Note: ISEL positive cells are seen blue; (c) pretreated with Losartan then $10 \%$ meconium. Seen decreasing ISEL-labeling (number and intensivity of blue-stained cells); (d) pretreated with caspase 3 inhibitor ZVADfmk and then $10 \%$ meconium (also seen a weaker ISEL staining); (e) instilled with ANG II (clearly seen positive ISEL-labeled cells). Magnification $400 \times$. 


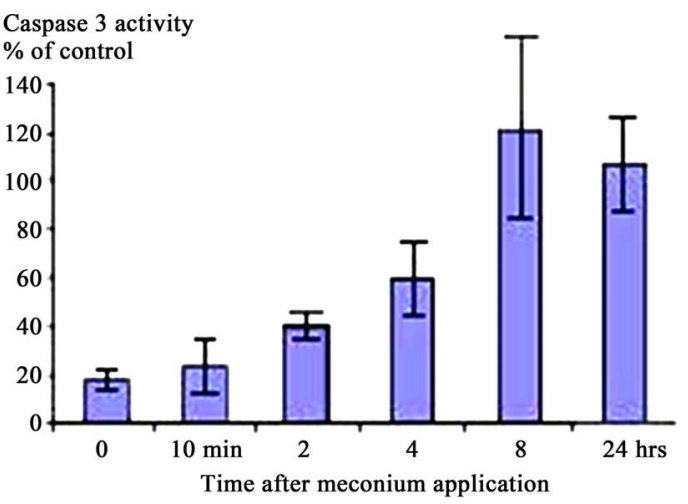

(a)

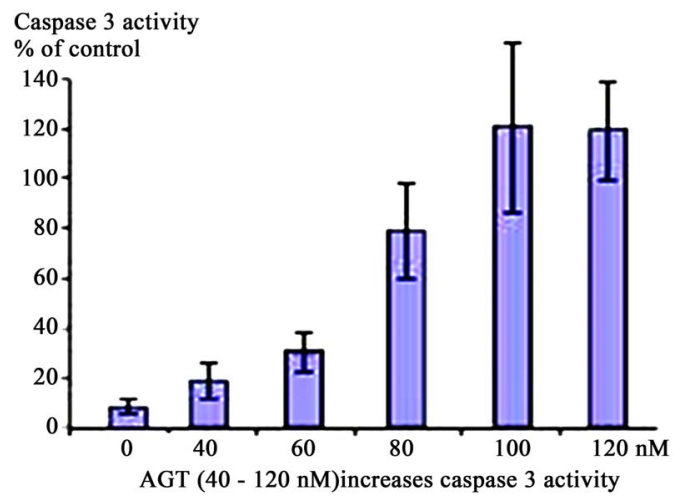

(b)

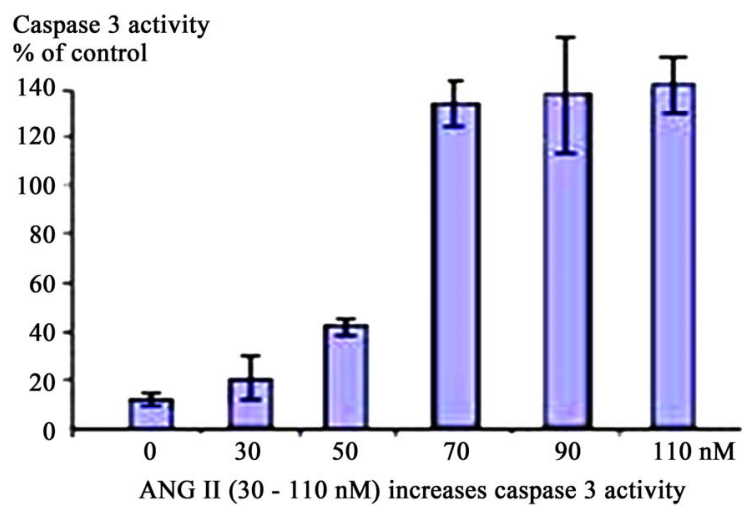

(c)

Figure 2. Activation of Caspase 3 in A549 cells in response to Meconium, AGT or ANG II. A549 cells were incubated with meconium (a), AGT (b) and ANG II (c) for 24 hr. Cells were trypsinized from cell culture vessels for assay (see Methods). All stimuli were able to induce Caspase 3 activity in a dose dependent manner. Maximal activation of Caspase 3 was seen 8 hr after meconium treatment (a). In A549 cells maximal activation of Caspase 3 was seen at AGT concentration of $100 \mathrm{nM}$. Higher concentrations did not show linear increase of apoptosis (b). Maximal Caspase 3 activation was observed at $50 \mathrm{nM}$ of ANG II. Higher concentrations were able to increase apoptosis, but not in a dose-dependent manner (c).

Apoptosis was also confirmed by classical nuclear fragmentation pattern as well as by visual analysis of DAPIstained cells. We demonstrated that in control cells about $4 \%$ displayed fragmented nuclei. At $8 \mathrm{hr}$ after ANG II treatment about $30 \%$ of cells displayed fragmented nuclei. Furthermore, the appearance of nuclear fragments correlated with a decrease of cell viability to $85 \%$ at $30 \mathrm{nM}$ of ANG II compared with control cells. Significant apoptosis was already observed in rabbit lungs treated by 100 $\mathrm{nM}$ of ANG II and A549 cells treated by ANG II at a concentration $50 \mathrm{nM}$. Apoptosis was also induced by purified AGT at the concentration of $5 \mathrm{mM}$. Further AGT was able to induce apoptosis with same potency as ANG II (not shown).

\subsection{Caspase 3 Inhibitor ZVAD-fmk Inhibits Apoptosis}

Treatment of A549 cells with 10\% meconium resulted in a significant, time-dependent increase in Caspase 3 activity (Figures 2 and 3). Caspase 3 activity increased $>5$-fold with a maximal peak level at $8 \mathrm{hr}(\mathrm{p}<0.05$, ANOVA). The activity of Caspase 3 was effectively blocked by the ANG II receptor AT1 antagonist, Losartan. These results demonstrate that Caspase 3 activity is related to expression of Angiotensin II receptors, particularly AT1 receptors (Figures 3(a) and (b)). The sequence-specific peptide inhibitor of caspase 3, ZVAD-fmk, drastically inhibited meconium-induced apoptosis of A549 cells, confirming that Caspase 3 is directly involved in meconium-induced apoptosis.

\subsection{Expression of AGT mRNA}

To determine if meconium treatment modified the local pulmonary RAS, we examined the expression of AGT in cultured A549 lung epithelial cells. Although saline had no effect on AGT mRNA (Figure 4, lane 2), meconium exposure increased the steady state level of AGT mRNA by 3 - 4 fold by $8 \mathrm{hr}$ exposure (Figure 4, lane 1). AGT expression was significantly inhibited by pretreatment of cells with the Caspase 3 inhibitor ZVADfmk (Figure 4, 
lane 4) or by the ACE inhibitor captopril (Figure 4, lane 5). To determine whether the rise in AGT mRNA was related to the meconium-induced apoptosis, we transfected primary cultures of A549 cells with antisense oligonucleotides against AGT or with scrambled-sequence control oligonucleotides. After a $4 \mathrm{hr}$ of transfection, the transfected antisense oligonucleotides inhibited the meconium-induced apoptosis by $>80 \%(\mathrm{p}<0.01)$, but the control nucleotides had no effect (data not shown). These data suggest that the synthesis and processing of AGT protein might be required for the meconium-induced cell apoptosis in human lung cells. Consistent with this interpretation, exposure to meconium significantly increased the amount of ANG II peptide nearly seven fold in human lung cells (data not shown).

\section{Discussion}

Recently it was shown that ANG II is able to induce apoptosis in cardiac myocytes [18] and endothelial cells [19]. We demonstrated here that ANG II-induces lung

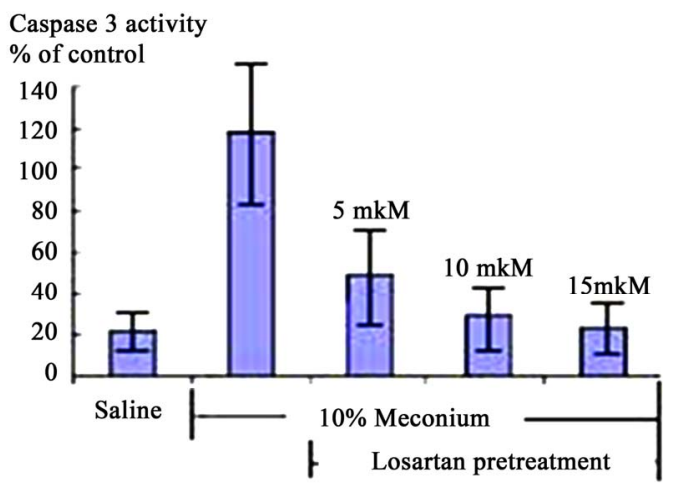

(a)

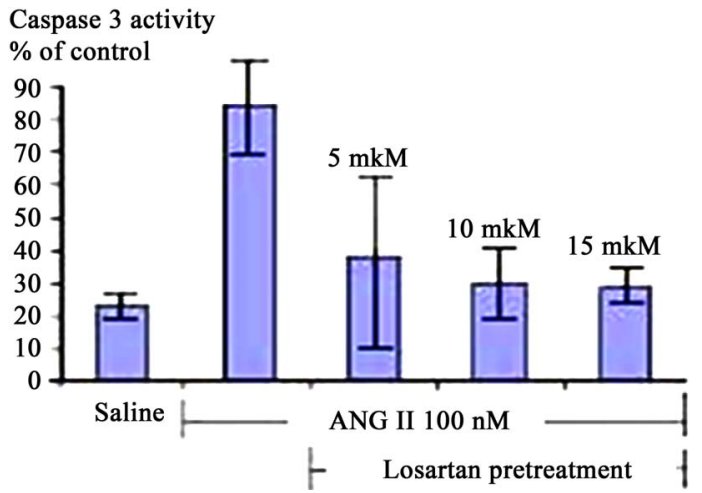

(c) cell apoptosis in physiologically relevant concentrations, consistent with results reported earlier [19]. We show further that ANG II induced apoptosis about 5 fold or more compared to saline controls.

In Situ End Labeling (ISEL) assay for nuclear fragmentation as well as terminal deoxynucleotidyltransferase dUTP nick end labeling (TUNEL) provides valuable information about meconium-induced lung cell apoptosis. Although recent studies demonstrate that ISEL labeling alone cannot clearly discriminate apoptosis, necrosis or DNA repair [20], in combination with other assays, for example with histological, immunohistochemistry, Caspase 3 activity and RT-PCR studies mentioned ISEL labeling can be a very valuable and important tool in detection and evaluation of apoptosis. Based on the above assays, we demonstrate that ANG II is able to generate apoptosis in A549 cells with efficiency less then 50\%. Meconium treatment can generate apoptosis which may reach up to $70 \%$ of total lung cell numbers.

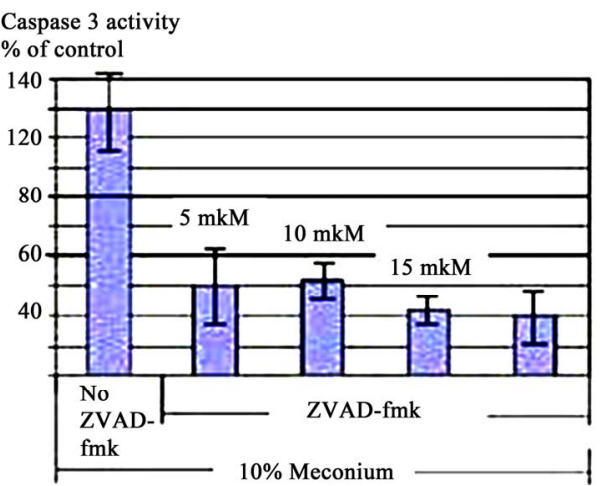

(b)

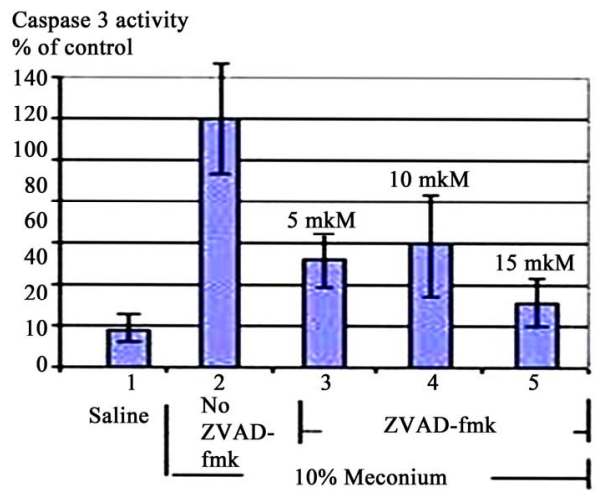

(d)

Figure 3. Caspase 3 Activation in A549 Cells is AT1 Dependent. (a) 10\% Meconium increases Caspase 3 activity in A549 cells. Note maximal activation at $8 \mathrm{hr}$ after meconium treatment; (b) Pretreatment of cells with Losartan 2 hr prior to meconium significantly inhibited meconium-induced Caspase 3 activation. Note: almost complete inhibition of meconium-induced Caspase 3 activation at concentration of Losartan 10 - $15 \mu \mathrm{M}$; (c) Pretreatment of cells by 10 - $15 \mu \mathrm{M}$ Losartan significantly inhibited also ANG II-induced Caspase 3 activation. Results are compiled from 4 independent experiments; (d) Caspase 3/cysteine protease protein-32/Yama activity measured at 0, 2, 4, 8 and 24 hr after meconium treatment. Caspase 3 activity is expressed in fluorescence units per milligram of protein per hour. 
ANG II was able to induce A549 cell apoptosis in concentration of $10 \mathrm{nM}$ and above. ANG II treated cells also express AGT mRNA (Figure 4), which directly supports the hypothesis of direct involvement of the RAS system in meconium-induced apoptosis. Induction of apoptosis by ANG II suggests that lung cells also express ACE-like activities which able to convert ANG I to ANG II. Inhibition by ACE inhibitors suggests that this conversion is done by $\mathrm{ACE}$ and is required for the induction of apoptosis.

The data also suggest that ANG II-induces apoptosis of lung cells via activation of the caspase cascade. ANG II treated cells exhibited an increase of Caspase 3 enzyme activity, which was significantly decreased by the pan-caspase inhibitor ZVAD-fmk. This finding demonstrates that activation of caspases plays central role in executing the ANG II stimulated apoptosis. This finding supports the role of ANG II as a potentially important contributor to the pathophysiology of MAS. Literature show that apoptotic effect of ANG II generally been attributed to stimulation of AT1 receptors [21]. However in non endothelial cells was demonstrated that ANG II was able to induce apoptosis via its AT2 receptors [10]. Together, these data demonstrated that ANG II is able to induce cell death by apoptosis. We showed that both meconium and ANG II were able not only increase of DNA fragmentation, which indicates induction of apoptosis, but also they significantly increased Caspase 3 activity and proteolytic cleavage of Caspase 3 .

Decreases of meconium- and ANG II-induced apoptosis by pretreatment with the AT1 receptor blockerlosartan and the caspase inhibitor-ZVAD-fmk demonstrated direct involvement of AT1 receptors in the induction of apoptosis. Blocking of AT2 receptors did not abo-

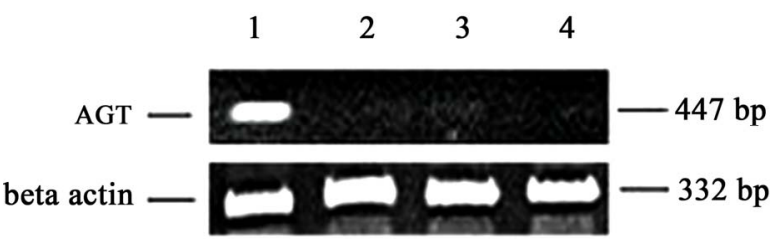

Figure 4. Inhibition of AGT expression by Caspase 3 inhibitor (ZVAD-fmk) or by Captopril pretreatment of A549 lung epithelial cells. A549 cells were incubated with $10 \%$ meconium (lane 1) or with normal saline (lane 2). Lane 3 shows cells pretreated with caspase inhibitor (ZVAD-fmk, lane 3) or Captopril (lane 4) and then exposed to $10 \%$ meconium. AGT mRNA expression was measured and compared between the groups. $300 \mathrm{bp}$ is a molecular weight marker shown on the right of the figure. $\beta$-actin expression was similar for all groups (not shown). Expression of AGT for meconium-treated cells (lane 1) was significantly greater (p $<0.05$, ANOVA) compared to all other groups. Results were repeated four times for statistic purposes and best experiment presented in figure. lish the apoptotic effect of ANG II. These data show that ANG II-induced apoptosis is not exclusively mediated by AT2 receptors.

ANG II has been shown to induce the production of oxygen radicals as superoxide anions in variety of cells [22]. The generation of reactive oxygen species has been demonstrated to be involved in mediation apoptosis via activation of cell death program and caspase activity [23].

Previous studies focused mostly on the effect of ANG II on promoting growth [24]. We are mostly focused on its injurious effect leading to cell apoptosis. Meconiuminjured lungs contain lesions in regions which are most likely due to an increase of apoptosis. Demonstrations that ANG II and meconium induce similar degrees of apoptosis may provide a mechanistic understanding of Renin-Angiotensin System involvement in MAS. The Renin-Angiotensin System may also play an important role in inducing coronary atherosclerosis and other diseases [25].

In summary, we demonstrate a similar degree of lung cell injury by meconium and ANG II via activation of caspase cascade and possibly AT1 receptors following activation of cell death program by apoptosis.

\section{Conclusions}

Our studies demonstrated that ANG II-induces apoptosis in human A549 epithelial cells as well as rabbit pup lung lavage cells in a degree comparable to a meconium-induced lung injury. This injury is accompanied with significant cell death by apoptosis, which can be effectively blocked by the ACE inhibitor captopril, the caspase inhibitor ZVAD-fmk or the AT1 selective antagonist losartan. These results demonstrated that meconium and ANG II induced lung cell injury induced via Caspase 3 cascade pathways in which AT1 plays an active role. In light of the availability and relative safety of angiotensin receptor blockers, participation of AT1 in meconiumand ANG II-induced lung cell apoptosis is a potentially clinically relevant observation that will be addressed in more detail in our future investigations.

\section{Acknowledgements}

We are thanking very much to our boss Dr. Garry Kruh, who tragically died earlier this year. And also Dr. William Beck and Dr. Howard Ozer who carefully reviewed and help us to complete a several project which we started with Dr. Garry Kruh. And also to Technician Huali Dong.

\section{REFERENCES}

[1] S. Kauffman, "Cell proliferation in the Mammalian Lung," International Review of Experimental Pathology, Vol. 22, 
1980, pp. 131-191.

[2] R. Mason and M. Williams, "Type II Alveolar Epithelial Cells," In: R. G. Crystal and J. B. West, Eds., The Lung: Scientific Foundations, Raven, New York, 1991, pp. 235246.

[3] A. Zagariya, R. Bhat, B. Uhal, et al., "Cell Death and Lung Cell Histology in Meconium Aspirated Newborn Lungs," European Journal of Pediatrics, Vol. 159, No. 11, 2000, pp. 819-826. doi:10.1007/s004310000581

[4] E. White, "Life, Death and the Pursuit of Apoptosis," Genes \& Development, Vol. 10, No. 1, 1996, pp. 1-15. doi:10.1101/gad.10.1.1

[5] R. Wang, G. Alam, A. Zagariya, et al., "Apoptosis of Lung Epithelial Cells in Response to TNF $\alpha$ Requires Angiotensin II Generation de novo," Journal of Cellular Physiology, Vol. 185, No. 2, 2000, pp. 253-259. doi:10.1002/1097-4652(200011)185:2<253::AID-JCP10 $>$ 3.3.CO;2-R

[6] A. Zagariya, S. Mungre, R. Lovis, et al., "Tumor Necrosis Factor Alpha Gene Regulation: Enchantment of $\mathrm{C} /$ EBP $\beta$-Induced Activation by c-Jun," Molecular and Cellular Biology, Vol. 18, No. 5, 1998, pp. 2815-2824.

[7] R. Wang, A. Zagariya, E. Ang, et al., "FAS-Induced Apoptosis of Alveolar Epithelial Cells Requires ANG II Generation and Receptor Interaction," American Journal of Physiology, Vol. 277, No. 6, 1999, pp. L1245-1250.

[8] R. Wang, C. Ramos, I. Joshi, et al., "Human Lung Myofibroblast-Derived Inducers of Alveolar Epithelial Apoptosis Identified Angiotensin Peptides," American Journal of Physiology, Vol. 277, No. 6, 1999, pp. L1158-1164.

[9] D. Munzenmaier, "Greene Opposite Actions of Angiotensin II on Microvascular Growth and Arterial Blood Pressure," Hypertension, Vol. 27, 1996, pp. 760-766.

[10] T. Yamada, M. Horiuchi and V. Dzau, "Angiotensin Type 2 Receptor Mediates Programmed Cell Death," Proceedings of the National Academy of Sciences, Vol. 93, No. 1, 1996, pp. 156-160. doi:10.1073/pnas.93.1.156

[11] S. Kumar, "ICE-Like Proteases in Apoptosis," Trends in Biochemical Sciences, Vol. 20, No. 5, 1995, pp. 198-202. doi:10.1016/S0968-0004(00)89007-6

[12] D. Nicholson, A. Ali, N. Thornberry, et al., "Identification and Inhibition of the ICE/CED-3 Protease Necessary for Mammalian Apoptosis," Nature, Vol. 376, No. 6535, 1995, pp. 37-43. doi:10.1038/376037a0

[13] L. Harrison-Bernard, L. Navar, H. Ho, G. Vinson and S. El-Dahr, "Immunohistochemical Localization of ANG II AT1 Receptor in Adult Rat Kidney Using a Monoclonal Antibody," American Journal of Physiology, Vol. 273, No. 1, 1999, pp. F170-F177. doi:10.1097/00004872-199816010-00014
[14] R. Wang, A. Zagariya, O. Ibarra-Sunga, et al., "Angiotensin II Induced Apoptosis in Human and Rat Alveolar Epithelial Cells," American Journal of Physiology, Vol. 276, No. 5, 1999, pp. L885-L889.

[15] K. Lai, J. Leung, W. To, et al., "Gene Expression of the Rennin Angiotensin System in Human Kidney," Journal of Hypertension, Vol. 16, No. 1, 1998, pp. 91-102.

[16] P. Ponte, S. Ng, J. Engel, et al., "Evolutionary Conservation Is in the Untranslated Regions of Actin mRNAs: DNA Sequence of a Human $\beta$-actin cDNA," Nucleic Acids Research, Vol. 12, 1984, pp. 1687-1696. doi:10.1093/nar/12.3.1687

[17] S. Dimmeler, U. Rippmann, J. Weiland, et al., "Angiotensin II Induces Apoptosis of Human Endothelial Cells," Circulation Research, Vol. 81, No. 6, 1996, pp. 970-976.

[18] J. Kajstura, A. Cigola, P. Malhotra, et al., "Angiotensin II Induces Apoptosis of Adult Ventricular Myocytes in Vitro," Journal of Molecular and Cellular Cardiology, Vol. 29, No. 3, 1997, pp. 859-870.

[19] S. Dimmeler, S. Brinkmann and E. Neugebauer, "Endotoxin-Induced Changes of Endothelial Cell Viability and Permeability: Protective Effect of a 21-Aminosteroid," European Journal of Pharmacology, Vol. 287, No. 3, 2005, pp. 257-261. doi:10.1016/0014-2999(95)00499-8

[20] B. Grasp-Kraup, H. Ruttkay-Nedecky, H. Koudelka, et al., "In Situ Detection of Fragmented DNA Fails to Discriminate among Apoptosis, Necrosis and Autolytic Cell Death: A Cautionary Note," Hepatology, Vol. 21, No. 5, 1995, pp. 1465-1468.

[21] F. Lyall, F. Dornan, J. McQuen, et al., "Angiotensin II Increases Protooncogene Expression and Phosphoinisitide Turnover in Vascular Smooth Muscle Cells via the Angiotensin II AT1 Receptor," Journal of Hypertension, Vol. 10, No. 1, 1992, pp. 1463-1469. doi:10.1097/00004872-199210120-00005

[22] H. Oskarsson and D. Heistad, "Oxidative Stress Produced by Angiotensin Too: Implications for Hypertension and Vascular Disease," Circulation, Vol. 95, 1997, pp. $557-$ 559.

[23] M. Jacobson, "Reactive Oxygen Species and Programmed Cell Death," Trends in Biochemical Sciences, Vol. 21, No. 3, 1996, pp. 83-86.

[24] R. Ross, "Cell Biology of Atherosclerosis," Annual Review of Physiology, Vol. 57, 1995, pp. 791-804. doi:10.1146/annurev.ph.57.030195.004043

[25] F. Cambien, O. Poirier, L. Lecerf, et al., "Deletion Polymorphism in the Gene for Angiotensin-Converting Enzyme Is a Potential Risk Factor for Myocardial Infarction in Patients with Hypertention," New England Journal of Medicine, Vol. 324, 1992, pp. 1098-1104. 


\section{Abbreviations}

MAS, meconium aspiration syndrome

RAS, rennin-angiotensin system

AGT, angiotensinogen

ANG I, angiotensin I

ANG II, angiotensin II

ACE, angiotensin converting enzyme

RT-PCR, reverse transcriptase-polymerase chain reac- tion

TTBS, $0.05 \%$ Tween-20-Tris-bufered saline TNF $\boldsymbol{\alpha}$, tumor necrosis factor alpha

PBS, phosphate buffered saline

SDS, sodium dodecyle sulphate

BSA, bovine serum albumin

i.p, intraperitoneal 